\title{
Authentic Undergraduate Research in Plant Science: The Importance of Mentor-Student Relationships
}

\author{
Franziska C. Doerflinger ${ }^{\mathrm{a}}$, Amanda J. Able ${ }^{\mathrm{a}}$ and Beth R. Loveys ${ }^{\mathrm{a}}$ \\ Corresponding Author: Beth Loveys (beth.loveys@adelaide.edu.au) \\ ${ }^{a}$ School of Agriculture, Food \& Wine, The University of Adelaide, Waite Campus, PMB 1, Glen Osmond \\ SA 5064
}

Keywords: mentor, active learning, communication, research skill development; inquirybased learning

International Journal of Innovation in Science and Mathematics Education, 27(4), 27-46, 2019 Special Issue: Agricultural Education

\begin{abstract}
Active learning can improve student engagement and learning outcomes by encouraging students to use higher order thinking skills. One strategy is involving students in research during their undergraduate studies where students are given the opportunity to design, implement, analyse and present a scientific research experiment under the guidance of an academic mentor. This study evaluates the role the student-mentor relationship played in the value of the research project for both students and mentors in a level II plant science course. Survey data collected between 2015 and 2017 showed that the majority (80\% in 2017) of students agreed that the research project was a valuable part of the course. In addition, students found the interaction with their mentor was important. Communication between student and mentor was seen as very important with $90 \%$ of the student cohort indicating that they agreed or strongly agreed that communication was important to the research project. The vast majority of mentors (over 75\%) were able to see the value to students of the research project. The majority of mentors felt it was easy to communicate with their student group and that students were responsive to their suggestions. This study has shown that preparing both students and mentors for participation in an authentic research project has positive impacts on student engagement.
\end{abstract}

\section{Introduction}

The strategy to involve students in deliberate activities such as reading, writing and solving problems so that they engage in higher order thinking tasks such as analysis, synthesis and evaluation is the basis of active learning pedagogy (Bonwell \& Eison, 1991). There is substantial evidence that active learning, in its varied forms, improves student success across many STEM disciplines (Freeman et al., 2014). Allowing time and space in the curriculum for students to ask questions and empowering them to create their own answers can facilitate greater learning than simply presenting them with already determined knowledge. Strong positive links between active learning and the level of student engagement also exist (Deslauriers, Schelew, \& Wieman, 2011). Student 'engagement', has been defined as "the effort that students put into educationally purposeful activities" and has been shown to directly influence the achievement of the desired learning outcomes (Astin, 1993; Hu \& Kuh, 2002; Pascarella, Terenzini, \& Feldman, 2005). An alternative 
definition is "students' involvement with activities and conditions that are likely to generate high quality learning" (Australian Council for Educational Research, 2008). Creating engaged learners can be achieved through various means with ten conceptual areas identified by Zepke and Leach (2010) as key to improving engagement. Of these, the proposals for action that are potentially most important, in the context of undergraduate research, are "Create learning that is active, collaborative and fosters learning relationships" and "Recognise that teaching and teachers are central to engagement". Group undergraduate research is, by its very nature, active and collaborative and in the context of the research described here the role played by the teachers (mentors) is central to the level of student engagement. Numerous studies have found that close interaction with academic staff has a positive impact on student cognitive development. The interaction in a student-mentor relationship differs from that experienced in a tutorial setting in that the student to teacher ratio is much lower and the contact between students and mentors is more focused and working towards a shared goal (Pascarella, 1980; Terenzini \& Pascarella, 1980; Pascarella \& Terenzini, 1981; Endo \& Harpel, 1982; Elfner, McLaughlin, Williamsen, \& Hardy, 1985; Terenzini \& Wright, 1987).

Historically, many undergraduate programs have not focused on gaining and developing the skills needed for problem solving and creative thinking, despite these attributes being highly valued in the modern workforce, instead the focus has been mastery of factual knowledge within the field (Wright \& Boggs, 2002). However, problem solving should be central to any tertiary study (Ertmer, 2015) and as such, many tertiary institutions have made a paradigm shift to address the requirement for graduates to be able to solve complex and authentic problems. As curriculum moves away from the delivery of knowledge to building capability of students to discover and create new knowledge for themselves clearly increases student engagement (Prosser, Trigwell, \& Taylor, 1994; Donnelly \& Fitzmaurice, 2005; Prince \& Felder, 2006; Trowler, 2010). Providing students with the opportunity to create new knowledge (new to themselves or to the discipline) can be achieved by allowing students to participate in research that is integrated with teaching (Reisberg, 1998; Wright \& Boggs, 2002; Mears, 2013). Together these educational shifts encourage the development of habits which promote engagement and may lead to life-long learning (Madhuri \& Broussard, 2008; Loveys et al., 2014).

At the University of Adelaide a strong emphasis has been placed on involving undergraduate students with authentic research under the guidance of a research-active member of staff. Every undergraduate student undertakes a group research project in each year of their degree in all degree programs. Undergraduate research has been shown to improve the generic skill set of students and enhance their satisfaction with their degree program (Kardash, 2000; Hathaway, Nagda, \& Gregerman, 2002; Ishiyama, 2002; Bauer \& Bennett, 2003;Willison \& O'Regan, 2007). As mentioned above, research requires active engagement by students over an extended period of time (Seel, 2011). Key components of successful undergraduate research projects are: (i) a question which is anchored in a real-world problem, which is meaningful to the students; (ii) collaboration between students (and mentors); and; (iii) involvement of students in investigations which allow them to learn concepts, apply information and create artefacts that represent their knowledge about the derived question (Albanese \& Mitchell, 1993; Jones, Rasmussen, \& 
Moffitt, 1997; Donnelly \& Fitzmaurice, 2005; Bell, 2010; Biggs and Tang, 2011; Seel, 2011). By participating in research, the student not only creates knowledge but also uses existing knowledge to form associations and networks within their own cognitive framework and ultimately gain a deeper understanding of a particular topic (Biggs \& Tang, 2011). Indeed, we have previously shown that the use of group research projects that are guided by 'expert' mentor(s), improves second year undergraduate perceptions of their own understanding of basic and applied concepts in plant science (Loveys et al., 2014).

Although a group research project can provide an environment conducive to the development of skills such as planning, self-reflection and self-regulation; it will not be a successful learning experience without guidance from experienced staff (Ertmer, 2015) with close personal contact shown to contribute to effective teaching (Von Humboldt, 1793; Albritton, 2006; Meier \& Schimank, 2009). In combination with guidance from research academics, careful scaffolding of research related skills also appears necessary for student success and engagement in undergraduate research (Loveys et al., 2014).

This paper describes a case study in mentor-led, discovery learning at the University of Adelaide and an evaluation of the role that the mentor-student relationship played in the value of undergraduate research. It was hypothesised that a strong connection between the student group and the mentor fosters a greater 'buy in' by the students and therefore enhances their engagement leading to improved learning outcomes and a better understanding of the topic. The results of the student surveys and focus groups are discussed to determine the value placed on student interaction with their mentor and the level to which this impacted the success of authentic undergraduate research. Defining and measuring success has been widely acknowledged in the literature as "necessarily complex and broad" (York, Gibson, \& Rankin, 2015, p. 9). Unsurprisingly academic grades are a common measure with a comprehensive literature review by York et al. (2015) revealing that over $50 \%$ of published papers use academic grades as a measure of student success. Also investigated was the type of information mentors require in order to be most effective in their role. The main aim of the research was to establish whether the involvement and engagement of the mentor, especially with improved mentoring skills, contributed to improved research skill development and engagement by students leading to an improved ability to solve real world problems. The outcomes of the survey and focus groups were used to create an induction workshop to better prepare mentors for guiding undergraduate research projects.

\section{Case study details}

This research took place within a level II plant science course. Students had a central role in the planning, design, execution, analysis and presentation of scientific projects. Mentors were volunteers and were recruited by a school-wide call for research staff (including tenured academic staff, post-doctoral fellows, senior $\mathrm{PhD}$ students and early career researchers) to volunteer their time to mentor undergraduate students. Expert mentors proposed the broad areas of research in which the experiments took place. Often the projects were part of larger research questions and thus the results were not known. The projects ran over the whole 12 week semester with a concentrated data collection period of four to five weeks. Projects took place in research or teaching laboratories, glasshouses, 
controlled environment rooms and/or University orchards. Examples of the types of projects undertaken by student groups are listed below:

- Root growth and hormones in acidic conditions

- Early yield prediction in grapevines

- Resistance to cereal cyst nematodes

- Responses of durum wheat to varying soil nitrogen supply

- Light and temperature effects on postharvest quality

- Exploiting cereal developmental mutants for hybrid seed production

Students self-enrolled in projects via the learning management system where a brief synopsis of the broad project area informed their project selection. Group size was limited to six students. At the end of the 12 week period students presented their research findings in a whole class symposium as an oral presentation. All mentors were in attendance but not involved in assessment. Two academic staff members assessed the oral presentations.

The mentor induction workshop was developed from student and mentor focus groups and survey feedback. The motivation for developing the mentor induction workshop was to improve the experience for both mentors and students. Many of the volunteer mentors had not been involved in undergraduate teaching for many years, if at all, therefore the expectations of mentors was often misaligned with student ability. Anecdotal feedback from mentors and students prior to 2016 indicated that better preparing mentors will have positive impacts on student experience during group research projects.

\section{Mentor induction workshop details}

Data collected in 2016 informed the development of a mentor induction. The workshop was designed to provide mentors with:

- Clear guidelines for their role in guiding students in the research process

- An overview of the academic background of the students

- The course load of the majority of students

- The level of knowledge to be expected in areas of biology, chemistry and statistics

- Details of the timeline and assessment of the research projects

- The resources available for projects

- Resources for managing group dynamics/conflict

The interactive workshop ran for 1one and a half hours and all mentors attended. Mentors were asked to contribute their own thoughts and ideas about their roles as mentors and also to discuss with each other the ways that had interacted with students in the past. This sharing of practice created a supportive environment and began building a community in which mentors could support one another. All mentors (36) attended the workshop.

\section{Methods}

The target course for this study was a second year plant science course (Foundations in Plant Science). Students who completed the course in 2015, 2016 and 2017 were invited to take part in the study. Mentors who had been involved with the research project 
component in 2016 and 2017were also asked to be part of the study. Students and mentors were surveyed and invited to participate in focus groups during and after taking part in a group undergraduate research project. Participation in surveys and/or focus groups was voluntary and survey responses were anonymous. The data was coded and randomised so no association with any specific person was possible. Ethics approval for data collection was gained from the University of Adelaide's Human Ethics Research Committee before the start of the project (H-2016-118).

\section{Student and mentor surveys}

A survey containing 15 questions [14 of which had a 5-point Likert scale (Likert, 1932) and one open-ended question] was administered to students in class or via email (Table 1). The 5-point Likert scale was used to show their level of agreement from strongly agree, agree, neutral, disagree to strongly disagree for each statement as per Joshi, Kale and Chandel (2015). The survey also included five demographic questions: gender, age group, years at the University (year at university), international or domestic student status and in which Bachelor degree (Agricultural Sciences, Viticulture and Oenology, or Applied Biology) the student was enrolled. Total student enrollments in the course varied from 74 in 2015, 94 in 2016 and 110 in 2017. The number of respondents varied in each year of the study being; $\mathrm{n}=35, \mathrm{n}=78 ; \mathrm{n}=88$ in 2015,2016 and 2017 respectively

\section{Table 1: Questions asked in the 2015, 2016 and 2017 student survey and the question cluster grouping.}

\begin{tabular}{|c|c|c|}
\hline Question & How the question was asked in the survey & Question Cluster \\
\hline Q1 & The group research project was a valuable part of the course: & Research project \\
\hline Q2 & $\begin{array}{l}\text { The group research project allowed me to develop skills that } \\
\text { have been or will be useful to my future study: }\end{array}$ & Research project \\
\hline Q3 & $\begin{array}{l}\text { Our group mentor was very involved with helping us plan } \\
\text { our project: }\end{array}$ & $\begin{array}{l}\text { Mentor } \\
\text { leadership/guidance }\end{array}$ \\
\hline Q4 & $\begin{array}{l}\text { Our group mentor communicated clearly with us throughout } \\
\text { the project period: }\end{array}$ & $\begin{array}{l}\text { Mentor } \\
\text { communication }\end{array}$ \\
\hline Q5 & Our group mentor met with us regularly: & $\begin{array}{l}\text { Mentor } \\
\text { communication }\end{array}$ \\
\hline Q6 & $\begin{array}{l}\text { We were able to contact our mentor if we had questions } \\
\text { about our project: }\end{array}$ & $\begin{array}{l}\text { Mentor } \\
\text { communication }\end{array}$ \\
\hline Q7 & $\begin{array}{l}\text { Our group mentor had a good understanding of the breadth of } \\
\text { our experience with scientific research: }\end{array}$ & $\begin{array}{l}\text { Mentor } \\
\text { communication }\end{array}$ \\
\hline Q8 & $\begin{array}{l}\text { Our group mentor provided support during our data } \\
\text { collection: }\end{array}$ & $\begin{array}{l}\text { Mentor } \\
\text { communication }\end{array}$ \\
\hline Q9 & $\begin{array}{l}\text { Our group mentor ensured that we understood the theory } \\
\text { behind our project: }\end{array}$ & $\begin{array}{l}\text { Mentor } \\
\text { communication }\end{array}$ \\
\hline Q10 & Our group mentor helped us to work effectively as a group: & $\begin{array}{l}\text { Mentor } \\
\text { leadership/guidance }\end{array}$ \\
\hline
\end{tabular}




\begin{tabular}{cll} 
Q11 & $\begin{array}{l}\text { We learnt a lot about how to conduct a scientific experiment } \\
\text { from our mentor: }\end{array}$ & $\begin{array}{l}\text { Mentor } \\
\text { communication }\end{array}$ \\
\hline Q12 & $\begin{array}{l}\text { Interacting with our mentor inspired me to think about a } \\
\text { research career: }\end{array}$ & Research Career \\
\hline Q13 & $\begin{array}{l}\text { Contact with our group mentor allowed me to expand my } \\
\text { professional networks: }\end{array}$ & Research Career \\
\hline Q14 & $\begin{array}{l}\text { I felt that by the end of the group project I was confident to } \\
\text { ask our mentor for advice: }\end{array}$ & $\begin{array}{l}\text { Mentor } \\
\text { leadership/guidance }\end{array}$ \\
\hline Q15 & $\begin{array}{l}\text { In the space below please add any other comments about the } \\
\text { group project in Foundations in Plant Science: }\end{array}$ & \\
\hline
\end{tabular}

Mentors were also surveyed, via email, using 14 5-point Likert scale questions, one openended question (Table 2) and three demographic questions (gender, age group and years working at the University). Mentors from 2016and 2017 were invited to participate $(n=25$ in 2016 and 36 in 2017). In 2017, minor changes were made to the questions asked of mentors, question 3 was re-worded to " $\mathrm{Q} 3$. The information provided to me at the Mentor Induction Workshop prepared me for my role as a mentor" and Q15 was added "Q15. Throughout the course of the project, communication from the project coordinator kept me informed of what was expected of me and the students".

Table 2: Questions asked in the 2016 mentor survey (pre-workshop) and 2017 and the cluster groups of questions

\begin{tabular}{|c|c|c|}
\hline Question & How the question was asked in the survey & Question cluster \\
\hline Q1 & I was pleased to volunteer my time to be a group mentor: & Involvement \\
\hline Q2 & The time commitment required to be a mentor was excessive: & Involvement \\
\hline Q3 & $\begin{array}{l}\text { The information provided to me at the beginning of the course } \\
\text { prepared me for my role as a mentor: }\end{array}$ & Expectations \\
\hline Q4 & I knew what would be expected of me as a mentor: & Expectations \\
\hline Q5 & $\begin{array}{l}\text { The skills of the students in my group were at the level I expected of } \\
\text { second year under graduates: }\end{array}$ & Expectations \\
\hline Q6 & $\begin{array}{l}\text { The students in my group had developed a realistic experimental plan } \\
\text { for us to work on together: }\end{array}$ & Expectations \\
\hline Q7 & I was able to communicate with the students in my group easily: & Communication \\
\hline Q8 & $\begin{array}{l}\text { The students in my group were responsive to my suggestions and } \\
\text { feedback regarding their project: }\end{array}$ & Communication \\
\hline Q9 & The students appeared to be engaged with the group research project: & Communication \\
\hline Q10 & The students worked well as a team: & Expectations \\
\hline
\end{tabular}


Q11 The students knew what was expected of them: Expectations

\begin{tabular}{cll}
\hline Q12 & $\begin{array}{l}\text { I was able to see the benefits of being involved in an undergraduate } \\
\text { research project: }\end{array}$ & Expectations \\
\hline Q13 & I would agree to be a mentor again if asked: & Reinvolvement \\
\hline Q14 & $\begin{array}{l}\text { I would recommend acting as an undergraduate project mentor to } \\
\text { colleagues: }\end{array}$ & Reinvolvement \\
\hline Q15 & $\begin{array}{l}\text { In the space below please add any other comments about the group } \\
\text { project in Foundations in Plant Science: }\end{array}$ & \\
\hline
\end{tabular}

\section{Focus groups}

All students were invited to attend focus groups in 2016 (see questions below). The focus group for the 2015 cohort had a total of three female students. The focus group for the 2016 cohort had a total of nine students from both genders (seven female, two male) and a mix of project groups. Student focus group discussions were not recorded but the facilitator and an observer took detailed notes. All mentors were invited to participate in the focus group in 2016 (see questions below). A total of 11 mentors attended a focus group meeting. Focus groups for students and mentors were run only in 2016 due to funding constraints. Surveys were administered in both 2016 and 2017.

Student focus group questions

1. What did you think about the group project in Foundations in Plant Science?

2. What were some of the best aspects of the group project?

3. What were some of the worst aspects of the group project?

4. Were there any aspects about the group project that surprised you or you were not expecting?

5. Is there anything from the experience that you have used again? eg. A skill such as working effectively in a team

6. Did you enjoy interacting with your mentor?

7. Did your mentor appear to enjoy meeting with you?

8. Was the communication with your mentor clear so that you knew what was required of you and why?

9. Was your mentor open to your suggestions about things you could try or change to make your project better?

10. Did your mentor inspire you to think more deeply about your project topic?

11. Did getting to know a research active mentor make you consider more seriously a research career yourself?

12. Is there anything else you would like to say about the group project or the role of your mentor?

\section{Mentor focus group questions}

1. Was this the first year you were involved in an undergraduate small group discovery project?

2. What were some of the best aspects of being a group mentor?

3. What were some of the worst aspects of being a group mentor? 
4. Were there any aspects about being a group mentor that surprised you or you were not expecting?

5. Did you feel prepared for being a mentor?

6. Did you know what to expect of $2^{\text {nd }}$ year students?

7. Did your group seem to work effectively as a team?

8. Did you enjoy interacting with your group of students?

9. Did your students appear to enjoy meeting with you?

10. Was the communication with your group clear so that you were confident that the group knew what was required of them?

11. Did your student group make suggestions about things they could try or changes they would like to make to their project?

12. Did you feel that the students were able to think deeply or creatively about their project topic?

13. Did your interaction with your student group encourage you to think about the potential of taking on one of them as an honours or PhD student?

14. Is there anything else you would like to say about the group project or your role as a mentor?

\section{Analysis and statistics}

Likert scale data was analysed using SPSS Statistics Version 24 (IBM Corp. Released 2016. IBM SPSS Statistics for Windows, Version 24.0. Armonk, NY: IBM Corp). The Likert scale answers were coded as Strongly agree $=5$ to Strongly Disagree $=1$ and number of responses in each category for each question was counted. For the analysis, the answers were classified as ordinal variables as per the suggestion of Boone and Boone (2012). The answer data was analysed using Chi-square $\left(\mathrm{X}^{2}\right)$ test to determine if there were relationships between the survey question answers and demographics of the students and mentors. Chi-square was also used to determine if there were relationships between different questions (Table 3 and 4). Due to similarity in attitude towards the survey questions for students in the 2015 and 2016 cohorts, the data was combined for statistical analysis. Data from 2017 was analysed separately. Student survey answers were also grouped into similar themes ("question cluster"), as described in Table 1 and 2, in order to make broad generalisations around key components of the mentor-student interaction. 
Table 3: Chi-square $\left(\mathrm{X}^{2}\right)$ results for the combined student data (2015 and 2016) demographics compared to each question; shown are only such combinations which have a significance level for the asymptotic significance of $p \leq 0.05$

\begin{tabular}{|c|c|c|c|}
\hline $\begin{array}{l}\text { Pair of demographic } \\
\text { data and question }\end{array}$ & $\begin{array}{c}\text { Pearson } \\
\text { Chi-Square } \\
\text { (X2) } \\
\end{array}$ & $\begin{array}{c}\text { Asymptotic } \\
\text { Significance (2-sided) }\end{array}$ & Directionality \\
\hline Gender * Q3 & 10.065 & 0.018 & $\begin{array}{l}\text { Female - agree more } \\
\text { strongly }\end{array}$ \\
\hline Gender * Q7 & 8.313 & 0.040 & $\begin{array}{l}\text { Male - agree more } \\
\text { strongly }\end{array}$ \\
\hline Gender * Q10 & 11.880 & 0.008 & $\begin{array}{l}\text { Male - agree more } \\
\text { strongly }\end{array}$ \\
\hline Age group * Q1 & 19.564 & 0.021 & $\begin{array}{l}\text { Younger students } \\
\text { agree }\end{array}$ \\
\hline Age group * $\mathrm{Q}^{2}$ & 21.760 & 0.040 & $\begin{array}{l}\text { Younger students } \\
\text { agree }\end{array}$ \\
\hline Age group * Q3 & 21.760 & 0.040 & $\begin{array}{l}\text { Age bracket } 21-25 \\
\text { agrees more strongly }\end{array}$ \\
\hline Age group * Q4 & 21.183 & 0.012 & $\begin{array}{l}\text { Age bracket } 21-25 \\
\text { agrees more strongly }\end{array}$ \\
\hline Age group * Q9 & 19.053 & 0.025 & $\begin{array}{l}\text { Age bracket } 18-20 \\
\text { agrees more strongly }\end{array}$ \\
\hline Age group * Q11 & 23.418 & 0.005 & $\begin{array}{l}\text { Younger students } \\
\text { agree }\end{array}$ \\
\hline Age group *Q12 & 29.524 & 0.003 & $\begin{array}{l}\text { Younger students are } \\
\text { impartial or disagree }\end{array}$ \\
\hline Year at Uni * Q2 & 35.510 & 0.001 & $\begin{array}{l}\text { Year } 2 \text { and } 3 \text { agree } \\
\text { most }\end{array}$ \\
\hline Year at Uni *Q4 & 28.356 & 0.001 & $\begin{array}{l}\text { Year } 2 \text { and } 3 \text { agree } \\
\text { most }\end{array}$ \\
\hline Year at Uni *Q6 & 23.575 & 0.005 & $\begin{array}{l}\text { Year } 2 \text { and } 3 \text { agree } \\
\text { most }\end{array}$ \\
\hline Student Origin * Q1 & 12.022 & 0.007 & $\begin{array}{l}\text { International students } \\
\text { agree more strongly }\end{array}$ \\
\hline Student Origin *Q2 & 9.833 & 0.043 & $\begin{array}{l}\text { All international } \\
\text { students agree }\end{array}$ \\
\hline Student Origin *Q8 & 11.911 & 0.008 & $\begin{array}{l}\text { Domestic students } \\
\text { agree more strongly }\end{array}$ \\
\hline Student Origin * Q10 & 8.244 & 0.041 & $\begin{array}{l}\text { International students } \\
\text { are less positive }\end{array}$ \\
\hline Student Origin * Q12 & 12.761 & 0.013 & $\begin{array}{l}\text { Domestic students are } \\
\text { neutral or disagree }\end{array}$ \\
\hline Student Origin * Q13 & 16.347 & 0.003 & $\begin{array}{l}\text { International students } \\
\text { agree more strongly }\end{array}$ \\
\hline
\end{tabular}


Table 4: Chi-square $\left(\mathrm{X}^{2}\right)$ results for the 2017 student data demographics compared to each question; shown are only such combinations which have a significance level for the asymptotic significance of $p \leq 0.05$

\begin{tabular}{lccl}
\hline $\begin{array}{c}\text { Pair of demographic } \\
\text { data and question }\end{array}$ & $\begin{array}{c}\text { Pearson } \\
\text { Chi-Square } \\
\left(\mathbf{X}^{\mathbf{2}}\right)\end{array}$ & $\begin{array}{c}\text { Asymptotic } \\
\text { Significance (2- } \\
\text { sided) }\end{array}$ & Directionality \\
\hline Gender * Q13 & 1.407 & 0.009 & $\begin{array}{l}\text { Male students agree } \\
\text { slightly more } \\
\text { strongly }\end{array}$ \\
\hline Year at Uni * Q2 & 45.689 & 0.000 & $\begin{array}{l}\text { Second year students } \\
\text { agree more strongly }\end{array}$ \\
\hline Year at Uni * Q3 & 14.173 & 0.028 & $\begin{array}{l}\text { Students in later } \\
\text { years are impartial }\end{array}$ \\
\hline Year at Uni * Q13 & 21.622 & 0.042 & $\begin{array}{l}\text { Year 1 students } \\
\text { don't see the benefit }\end{array}$ \\
\hline Student Origin * Q1 & 9.792 & 0.020 & $\begin{array}{l}\text { Domestic students } \\
\text { are slightly less } \\
\text { optimistic }\end{array}$ \\
\hline
\end{tabular}

\section{Results}

\section{Student perception of group research projects}

Across all three student cohorts (2015-2017) the majority of students agreed that the research project was a valuable component of their plant science course (Q1, Figure 1) with the proportion of students who strongly agreed increasing from less than $10 \%$ in 2015 to $25 \%$ for the 2017 cohort. During this time, support (by way of explicit tutorials) provided to students in terms of engaging in the research process was improved. This is reflected in increasing proportions of students, between 2015 and 2017, valuing the research skills that were developed by the group research project (Q2, Figure 1). Students in younger age brackets (18-20 years and 21-25 years), as well as international students indicated that they placed a greater value on group projects and the skills developed by group research projects compared to the more mature students (Table 3). Comments from focus group meetings support the findings of the survey:

It was a good addition to the course and since we are making a presentation we had to really understand the topic.

I chose my project as it interested me but the process involved showed me a lot of new skills and challenged me to get out of my comfort zone and work cooperatively with team members and mentors. Our mentors were extremely helpful throughout the project, ensuring we understood all of our steps, the direction we were taking and final results - very positive project. 


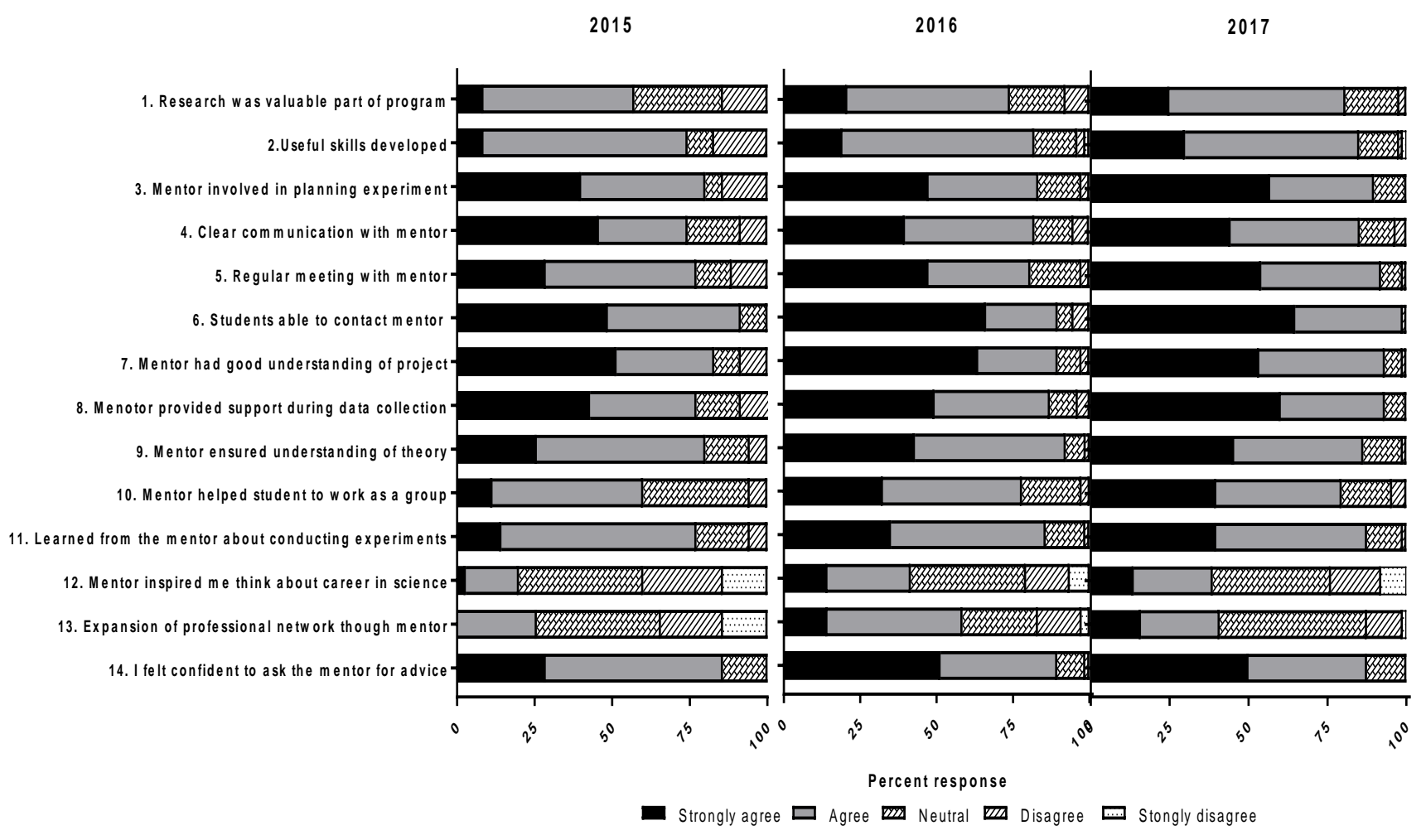

Figure 1: Student responses to 5-point Likert-scale survey regarding a group research project in level ii plant science. (Participants were involved in the group research project in either 2015- $n=35 ; 2016-n=78 ; 2017-n=88$. The mentors involved during 2016 and 2015 had not participated in the mentor induction workshop while mentors in 2017 had participated in the mentor induction workshop.)

Interestingly, when survey question clusters were grouped into themes (Research project; Mentor leadership/guidance; Mentor communication), the positive responses (strongly agree and agree) before and after the addition of the mentor induction workshop were similar for the "research projects" theme (Figure 2).

The role of the mentor in undergraduate research projects

Regardless of year surveyed, student-mentor interaction was important. The majority of students felt that mentors were very involved in planning the experiment (Q3), clearly communicated with them (Q4), met with them regularly (Q5), were easily contactable (Q6), had a good understanding of the project (Q7), provided support during data collection (Q8), ensured understanding of theory (Q9), helped students work as a group (Q10), taught students about conducting experiments (Q10) and were approachable for advice (Q14) (Figure 1). 
a

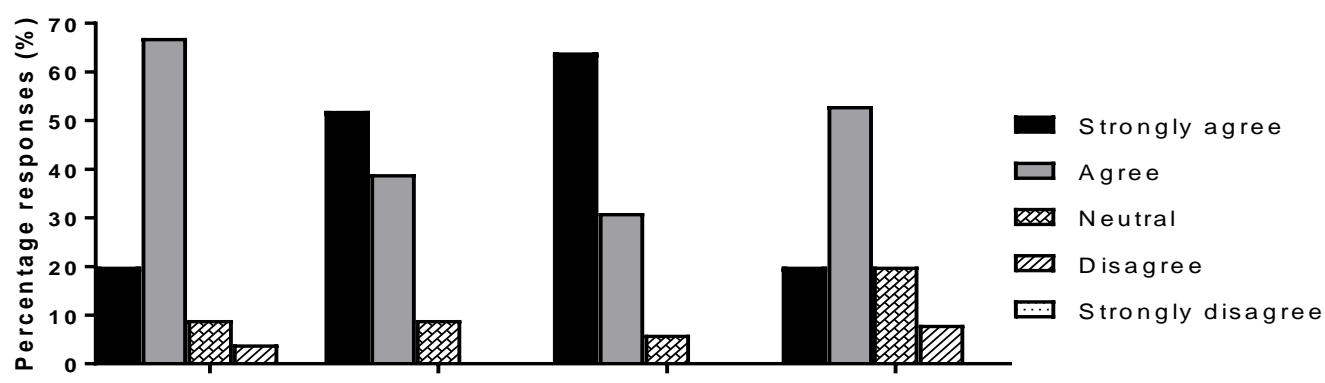

b

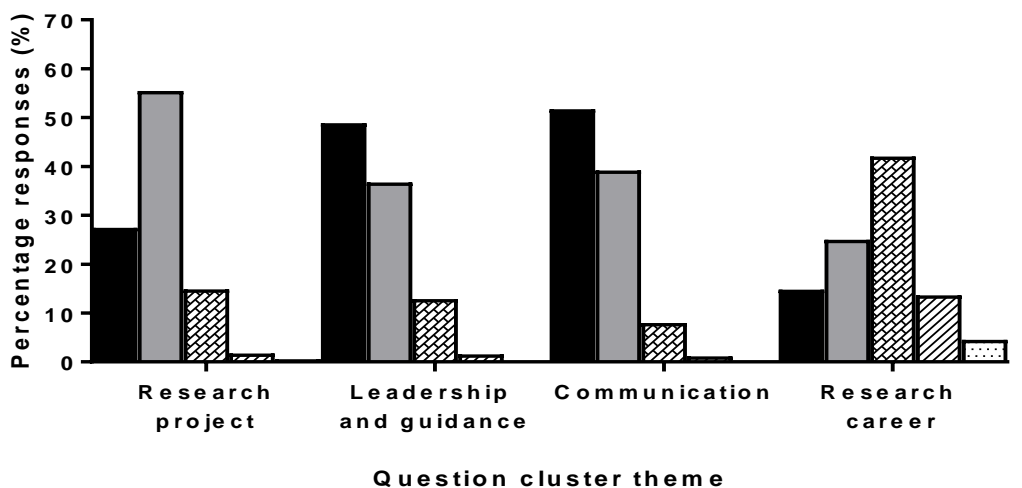

Figure 2: Student survey answers to questions grouped by theme: research projects, mentor leadership and guidance, communication and research career measured using 5-point Likert-scale in (a) 2016 prior to mentor induction workshop and (b) 2017 after addition of mentor induction workshop.

However, responses towards questions relating to mentor communication (Q4), mentor ensuring that the theory was understood (Q9) and learning from the mentor about scientific experiments (Q11) were significantly correlated with age group (Table 3. $\mathrm{P}=0.012,0.025$ and 0.005 for Q4, Q9 and Q11 respectively). In addition, responses towards questions relating to provision of support by the mentor during data collection (Q8) and helping students to work as a group $(\mathrm{Q} 10)$ were positively correlated with international status of the students. Female students reported a more positive attitude towards the mentor helping the students plan their experiment $(\mathrm{Q} 3, \mathrm{p}=0.018)$ and also agreed to a greater extent that the mentor helped them work effectively as a group (Q10, $\mathrm{p}=0.008)$. However, male students agreed more strongly that the mentors had a good understanding of the research project $(\mathrm{Q} 7, \mathrm{p}=0.04)$.

Students in the 2017 cohort, after mentor induction workshops were introduced, were more positive than earlier cohorts regarding their mentor's involvement in planning the experiment (Q3) and support in data collection (Q8) (Figure 1). The pattern of responses for the common theme of "mentor leadership and guidance" was not significantly different 
before and after the introduction of a mentor induction workshop (Figure 2). However, the leadership and guidance provided by the mentor was considered important with at least $50 \%$ of students strongly agreeing with questions related to this area of interaction with their mentor. Furthermore, the proportion of students who strongly agreed that they felt confident to ask their mentor for advice increased from $25 \%$ to over $50 \%$ between 2015 and 2017 (Figure 1). The positive role the mentor played in engaging students was supported by focus group comments:

Great project - great mentor.

She (the mentor) reached out and offered to meet and help us often, with simple tasks we said we were ok. Good help of mentor with statistics and data analysis.

"Communication" was also important, regardless of year, with close to $90 \%$ positive responses (strongly agree and agree) for that cluster of questions (Figure 2). From 2015 to 2017, there was also an increase in positive responses for regularly meeting with the mentor (Q5) and being able to contact the mentor (Q6).

One of the most difficult roles for a mentor is managing group dynamics. Encouragingly, students felt more positive about the role the mentor played in helping their group perform well as a team in 2017 compared with students in 2015. The mentor induction workshop aimed to give the mentors more insight into the prior experience of level 2 undergraduates of working as a team. It also gave mentors tools for coping with dysfunctional groups such as encouraging communication between group members. In $2015,11 \%$ of students strongly agreed that their mentor(s) helped them to work as a team. In 2017, this had increased to $40 \%$ of students (Figure 1, Q10). This was supported by focus group comments:

...our mentor was very helpful and supportive. Helped to engage me for more of the research topics.

[The project] allowed me to work cooperatively with team members and mentors.

\section{Research career}

Survey questions 12 and 13 relate to the attitude of students towards research and whether the interaction with the mentor inspired them to think about a career in research or expanded their professional network. When clustered under the theme "Research Career", regardless of year, there was a variety of responses but the majority of students were either positive or neutral in their attitude (Figure 2). The student's attitude towards whether their interaction with their mentor inspired them to think about a career in research (Figure 1, Q12) was spread across all Likert categories. In 2015, 20\% of students agreed that their mentor inspired them to think about a research career. This increased to $41 \%$ of the student cohort in 2016 and $39 \%$ in 2017. Importantly, in 2015, none of the student cohort strongly agreed to the notion that interaction with a mentor expanded their professional network. However, in 2016 and 2017, up to $15 \%$ of students strongly agreed with this idea (Figure 1, Q13). Comments in 2017 supported the developing idea that undergraduate research can be important for a students' future career "[the project provided] good professional development". However, some students were not able to see the value in the research project, "Nothing against our mentor but I have zero desire to get into research." It is possible that the link between research and other competencies such as problem solving 
and critical thinking may not be clearly understood by level II students. Alternatively, students in applied discipline areas such as agriculture and viticulture may have less desire to undertake further research by way of honours or $\mathrm{PhD}$.

\section{Characteristics of mentors}

When comparing 2016 with 2017 mentor survey responses (Figure 3), there was a reduction in the proportion of responses in the strongly agree category between 2016 and 2017. Responses to all questions in 2017 were spread across all Likert options while in 2016 more responses clustered around the positive end of the Likert scale. Most of the mentors were in the age groups 25 to 35 and 35 to 45 with only $22.7 \%$ being in the oldest age group (45 to 55) in both years. Many of the mentors were post-doctoral fellows or PhD students. This indicated that mentoring was more popular for early career researchers with the mentoring process providing an opportunity for them to obtain experience in interacting with undergraduate students. This was supported by a focus group comment: "Mentoring is a good way to start interacting more with students and teach them new concepts."

Mentors in 2016 and 2017 agreed in both survey data and focus group meetings that participation in undergraduate research projects was a positive experience for them and that the time commitment required was not excessive (Figure 3). Most mentors (75\%) felt that they were aware of the student skill level that they could expect from a level II undergraduate and a similar proportion felt that they were able to communicate with their student group and the students were responsive to their suggestions. A greater proportion of mentors in 2017 felt that the information provided had prepared them for the role (Q3) and knew what was expected of them (Q4) compared to mentors in 2016, suggesting that the mentor induction workshop had some impact. Importantly, over $75 \%$ of the mentors agreed that undergraduate research was a valuable part of the curriculum. This was supported by focus group comments: "[The group project] was a good introduction to the process of original science research. 
2016

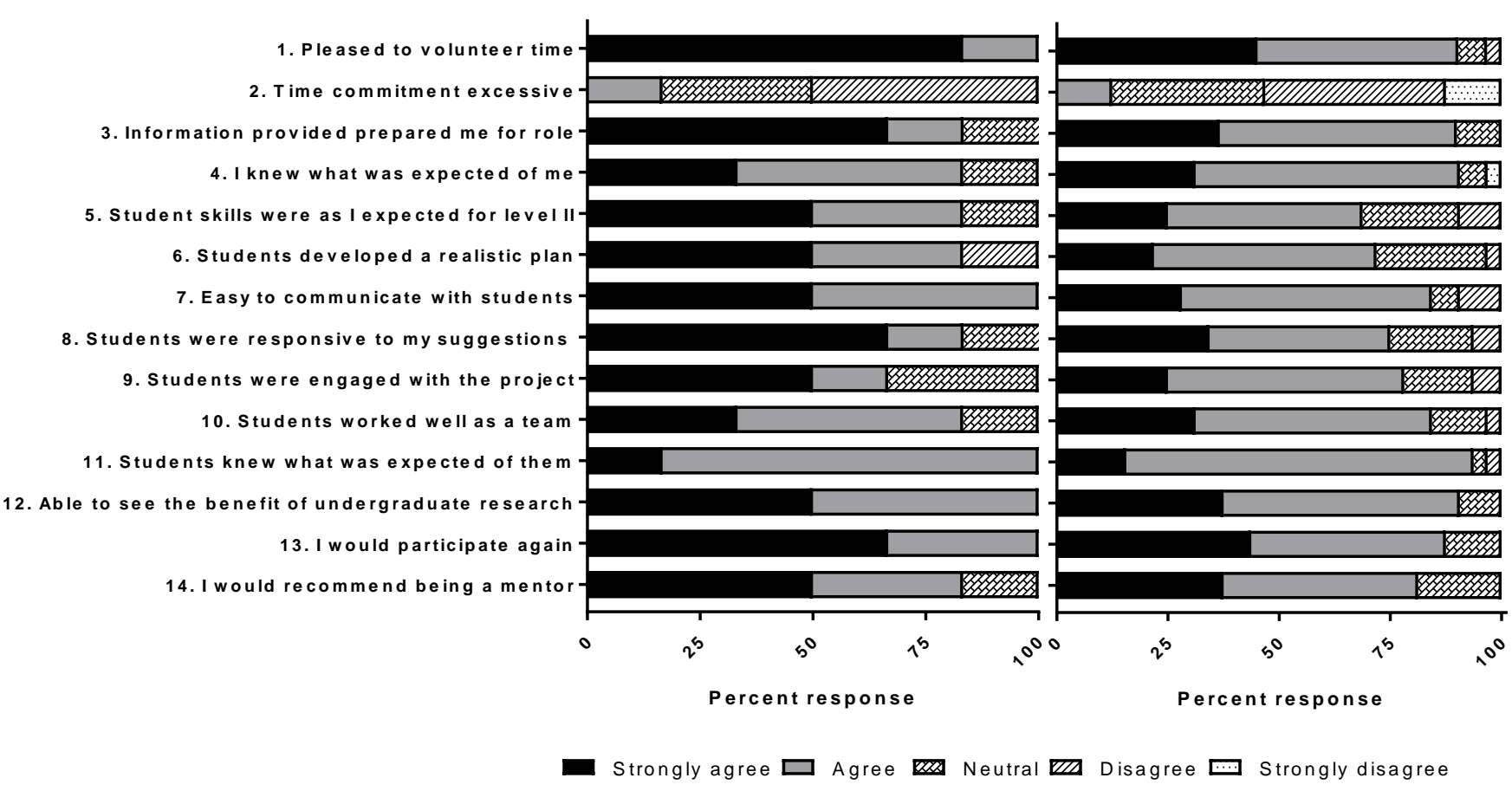

Figure 3: Reponses of mentors to 5-point Likert-scale survey regarding participation in small group undergraduate research project during 2016 and 2017. (All mentors involved in student research projects attended the induction workshop.)

\section{Discussion and conclusions}

There is little doubt that active learning has positive impacts on student engagement and thus learning outcomes for students in tertiary education. The large meta-analysis by Freeman et al., (2014) provided the first tangible evidence for the benefits of active learning across several STEM disciplines. The case study presented here examines a particular example of active learning commonly used in the field of science education, a group authentic research project. The focus for this study was examining the role of an academic mentor in adding value to the hands-on experience of research at an undergraduate level. Our results provide further evidence that experiential learning in science education is a valuable part of the curriculum not only for students but also for academics acting as mentors in a group research situation. In addition, providing students and mentors with scaffolded support to guide the research process improves the learning experience and outcomes for students.

An authentic group research project provides a multifaceted learning experience that addresses not only learning outcomes but also graduate attributes. Team and group work skills have long been identified as core competencies to be achieved by tertiary education (Johnson \& Johnson, 1990; Springer, Stanne, \& Donovan, 1999), and in tertiary education institutions these skills have been identified as an important graduate attribute across most degree programs including science degrees (Biggs \& Tang, 2011; Jones, Yates, \& Kelder, 
2011; Botwright Acuña et al., 2014; Botwright Acuña \& Able, 2016). Developing the skills to work as a team encompasses soft skills such as communication, conflict resolution and tolerance (Johnson \& Johnson, 1990). The ability to solve problems and resolve conflict are highly regarded skills in terms of graduates being work-ready (Pan \& Allison, 2010) and practicing these skills in a safe and secure environment such as an undergraduate research group project, allows students to gain experience. In this study, the majority of students agreed that all aspects of communication with their mentor were very important to the success of their research project along with the guidance that their mentor provided in terms of working as a team. In particular, students valued the ability to ask a mentor for advice to receive feedback, as per the focus group comment "Receiving feedback about results and progress was encouraging".

However, close to $20 \%$ of students had a neutral or negative response with regards to the mentor helping them work as a team or the value of research to their program. This may be a result of the possible perception that the research project feels as though it is a less authentic group-work situation because of the artificial construct of a team where there is no hierarchy and all individuals should contribute equally (Cohen \& Bailey, 1997). The strain of group work was succinctly described by this comment from a focus group interview:

I enjoyed the project part of the experience. Unfortunately members of my group really did not put any effort in and this had to be covered by the rest of the team, putting considerable strain on our time commitments and family lives.

However, the mentor may help to alleviate these tensions by providing subtle leadership and guidance, especially in the form of providing support in the planning of the experiment and during the data collection, attributes that were improved after mentor induction workshops were introduced. The positive benefits to mentor and mentee of providing some professional development to mentors to ensure they know how to mentor undergraduates in group research projects has been previously reported in the sciences (Stamp, TanWilson, \& Silva, 2015). This aspect is also important for the professional development of the early career researchers that act as mentors. Indeed, the finding that the introduction of the workshop also improved the mentors' knowledge of what was expected of them, supports work by Wallin and Adawai (2018) that early career researchers have three main entry points to help them define their role as a mentor: establishing the goals of the undergraduate research, knowing what the students expect of them, and how they should use their expert knowledge.

The increasingly diverse nature of the student cohort in terms of age, ethnic origin and previous educational background can provide challenges with regards to group work and managing group dynamics. In the example presented here, students formed groups based on a common interest for the project topic which often resulted in students with diverse backgrounds being required to work together. Younger students more readily agreed that the research project was a useful activity within the plant science courses than the more mature students, perhaps due to lower levels of skill development prior to participation in the research project. Mature students may have had the opportunity to develop such skills during previous study or employment. In addition, the attitude of mature students towards group work was less positive perhaps due to having experienced more of the so called "free 
riding" with regard to group work situations - that being where one or more individuals in a group do not contribute, instead letting others in the group do the work (Kapp, 2009), thus the mature students voiced reservations regarding the value of group work.

The ethnic background of students influenced their perceptions of group research projects, $100 \%$ of international students considered the research project a valuable component of a course while $74 \%$ of domestic students responded positively to this question (agree and strongly agree). This result seems surprising considering that international students appear to dislike group projects more than domestic students (information gathered from formal Student Experience of Learning and Teaching feedback, data not shown). International students also responded more positively when asked if the skills developed during the research project were valuable, $100 \%$ of respondents agreeing or strongly agreeing with the statement, compared to $74 \%$ of domestic students responding positively. This indicates that international students place greater value on the skills learned though group projects than domestic students. Gatfield (1999) found that international students were more satisfied with the peer assessment aspect of group work than Australian (domestic) students.

An important component of authentic research projects is that, by their very nature, they bring together key and threshold concepts within a discipline. A threshold concept is classified as a concept which transforms the understanding, interpretation, or viewing of something and without these concepts the learner will not be able to progress in their studies (Meyer \& Land, 2003; Meyer \& Land, 2005; Biggs \& Tang, 2011; Peter et al., 2014). Threshold concepts thus transform the comprehension of a student and change how a subject matter is viewed (Meyer \& Land, 2003). The learning outcomes addressed in the plant science courses described here include the ability of students to describe and discuss generalised plant responses to internal and external biotic and abiotic factors. Some students might not see the value in the material, which from their point of view does not "directly" contribute to their field of interest. The mentor is in a unique position to put these generalised responses into specific and real-world context and also improve student engagement and retention of information to create a base for life-long learning habits. There is limited literature addressing this concept, however Candy (1995) suggests that one of the key roles of modern higher education is to create life long, self-directed learners by progressively giving students greater autonomy and thus confidence in their own ability to translate general observation to real-world scenarios.

This case study has shown that preparing both students and mentors for participation in a group research project has significant impacts on student engagement. When mentors are aware of what is expected of them and the academic level that can be expected of level II students they are better able to provide appropriate support to the students during their research project. The mentor induction workshop continues to be utilised in several courses in the Faculty of Science and a generic template of the workshop material is available university wide. 
International Journal of Innovation in Science and Mathematics Education, 27(4), 27-46, 2019

\section{Acknowledgments}

The authors thank the students who volunteered to participate in this study. Thanks also go to the wider project team Johannes Scharwies, Zeyu Zhao, Helen Brown and Eva Tomczyk. This research received no specific grant from any funding agency in the public, commercial, or not-for-profit sectors but was supported by a grant from the Office of the Deputy Vice Chancellor Academic, The University of Adelaide and ethics approval granted by the Human Research Ethics Committee (H-2016-118).

\section{References}

Albanese, M.A., \& Mitchell, S. (1993). Problem-based learning: A review of literature on its outcomes and implementation issues. Academic Medicine, 68, 52-81.

Albritton, F.P. (2006). Humboldt's unity of research and teaching: Influence on the philosophy and development of US higher education. Available at SSRN: https://ssrn.com/abstract=939811 or http://dx.doi.org/10.2139/ssrn.939811 (accessed January 22 2017)

Astin, A.W. (1993). What matters in college?: Four critical years revisited. Jossey-Bass San Francisco.

Australian Council for Educational Research (ACER) (2008). Attracting, engaging and retaining: New conversations about learning. Australasian Student Engagement Report: Survey of Student Engagement Australasian Survey of Student Engagement ACER, Camberwell; Victoria http://www.acer.edu.au/ausse (accessed January 2 2017).

Bauer, K.W., \& Bennett, J.S. (2003). Alumni perceptions used to assess undergraduate research experience. The Journal of Higher Education (74), 210-230.

Bell, S. (2010). Project-based learning for the 21st century: Skills for the future. The Clearing House: A Journal of Educational Strategies, Issues and Ideas, 83, 39-43.

Biggs, J.B., \& Tang, C. (2011). Teaching for quality learning at university: What the student does. Maidenhead: McGraw-Hill Education.

Bonwell, C.C., \& Eison, J.A. (1991). Active learning: Creating excitement in the classroom. 1991 ASHEERIC Higher Education Reports. ERIC Clearinghouse on Higher Education, Washington: The George Washington University.

Boone, H.N., \& Boone, D.A. (2012) .Analyzing Likert data. Journal of Extension (50), 1-5.

Botwright Acuña, T.L., Able, A.J., Kelder, J., Bobbi, P., Guisard, Y., Bellotti, W., McDonald, G., Doyle, R., Wormell, P., \& Meinke, H. (2014). Learning and Teaching Academic Standards Statement for Agriculture. Sydney: Office for Learning and Teaching.

Botwright Acuña, T.L., \& Able, A.J. (Eds.). (2016). Good practice guide: Threshold learning outcomes for agriculture. Sydney, Australia: Office for Learning and Teaching.

Candy, .P C. (1995) .Developing lifelong learners through undergraduate education. In L. Summers (Ed.), A Focus on Learning, (p ii-viii). Proceedings of the 4th Annual Teaching Learning Forum, Edith Cowan University, February 1995. Perth: Edith Cowan University. http://lsn.curtin.edu.au/tlf/tlf1995/candy.html

Cohen, S.G., \& Bailey, D.E. (1997). What makes teams work: Group effectiveness research from the shop floor to the executive suite. Journal of Management, 23, 239-290.

Deslauriers, L., Schelew, E., \& Wieman, C. (2011). Improved learning in a large-enrollment physics class. Science,13, 862-864.

Donnelly, R., \& Fitzmaurice, M. (2005). Collaborative project-based learning and problem-based learning in higher education: A consideration of tutor and student role in learner-focused strategies. In $\mathrm{G}$.

O'Neill \& B. McMullin (Eds.), Emerging issues in the practice of university learning and teaching (pp. 87-98). AISHE/HEA, Dublin.

Elfner, E.S., McLaughlin, R.K., Williamsen, J.A. \& Hardy, R.R. (1985). Assessing goal related student outcomes for academic decision-making. 25 $5^{\text {th }}$ Annual Forum of the Association for Institutional Research, (pp. 2-32), Portland.

Endo, J.J., \& Harpel, R.L. (1982). The effect of student-faculty interaction on students' educational outcomes. Research in High Education 16, 115.

Ertmer, P.A. (2015). Essential readings in problem-based learning. Purdue University Press, Indiana. 
International Journal of Innovation in Science and Mathematics Education, 27(4), 27-46, 2019

Freeman, S., Eddy, S.L., McDonough, M., Smith, M.K., Okoroafor, N., Jordt, H., \& Wenderoth, M. P. (2014). Active learning increases student performance in science, engineering, and mathematics. Proceedings of the National Academy of Sciences, 111(23), 8410-8415.

Gatfield, T. (1999). Examining student satisfaction with group projects and peer assessment. Assessment \& Evaluation in Higher Education, 24, 365-377.

Hathaway, R.S., Nagda, B.A., \& Gregerman, S.R. (2002). The relationship of undergraduate research participation to graduate and professional education pursuit: An empirical study. Journal of College Student Development, 43, 614-631.

Hu, S., \& Kuh, G.D. (2002). Being (dis) engaged in educationally purposeful activities: The influences of student and institutional characteristics. Research in Higher Education, 43, 555-575.

Ishiyama, J. (2002). Does early participation in undergraduate research benefit social science and humanities students? College Student Journal, 36, 380.

Johnson, D.W., \& Johnson, R.T. (1990). Social skills for successful group work. Educational Leadership, 47, 29-33.

Jones, B.F., Rasmussen, C.M., \& Moffitt, M.C. (1997). Real-life problem solving: A collaborative approach to interdisciplinary learning. Washington DC: American Psychological Association.

Jones, S., Yates, B., \& Kelder, J. (2011). Learning and Teaching Academic Standards Statement for Science. Sydney: Australian Learning and Teaching Council.

Joshi, A., Kale, S., Chandel, S., \& Pal, D. (2015). Likert scale: Explored and explained. British Journal of Applied Science \& Technology, 7, 396.

Kapp, E (2009). Improving student teamwork in a collaborative project-based course. College Teaching, $57,139-143$.

Kardash, C.M. (2000). Evaluation of undergraduate research experience: Perceptions of undergraduate interns and their faculty mentors. Journal of Educational Psychology, 92, 191-201.

Likert, R. (1932.) A technique for the measurement of attitudes. Archives of Psychology, 22 140, 55.

Loveys, B.R., Kaiser, .B.N., McDonald, G., Kravchuk, O., Gilliham, M., Tyerman, S., \& Able, A.J. (2014). The development of student research skills in second year plant biology. International Journal of Innovation in Science and Mathematics Education, 22(3), 15-25.

Madhuri, M., \& Broussard, C. (2008). "Do I need to know this for the exam?” Using popular media, inquiry-based laboratories, and a community of scientific practice to motivate students to learn developmental biology. CBE-Life Sciences Education, 7, 36-44.

Mears, A. (2013). Findings from student focus groups. In L. Kirkup, Inquiry-oriented learning in science: Transforming practice through forging new partnerships and perspectives (pp. 74-78). Canberra: Office of Learning and Teaching.

Meier, F., \& Schimank, U. (2009). Matthäus schlägt Humboldt? New Public Management und die Einheit von Forschung und Lehre. Beiträge zur Hochschulforschung ,31, 42-61.

Meyer, J.H.F., \& Land, R. (2003). Threshold concepts and troublesome knowledge- Linkages to ways of thinking and practising. In C. Rust, (Ed.), Improving student learning - theory and practice ten years $o$. Oxford: Oxford Centre for Staff and Learning Development (OCSLD), pp 412-424. Occasional Report,

Meyer, J.H.F., \& Land, R. (2005). Threshold concepts and troublesome knowledge (2): Epistemological considerations and a conceptual framework for teaching and learning. Higher Education, 49, 373-388.

Pan, W., \& Allison, J. (2010). Exploring project based and problem based learning in environmental building education by integrating critical thinking. International Journal of Engineering Education, 26, 547-553.

Pascarella, E.T. (1980). Student-faculty informal contact and college outcomes. Review of Educational Research, 50(4), $545-595$.

Pascarella, E.T., \& Terenzini, P.T. (1981). Residence arrangement, student/faculty relationships, and freshman-year educational outcomes. Journal of College Student Personnel, 22(2), 147-56.

Pascarella, E.T., Terenzini, P.T., \& Feldman, K.A. (2005). How college affects students. San Francisco: Jossey-Bass.

Peter, M., Harlow, A., Scott, J.B., McKie, D., Johnson, E.M., Moffat, K. \& McKim, A.M. (2014). Threshold concepts: Impacts on teaching and learning at tertiary level. Teaching and Learning Research Institute, Wellington. 
Prince, M.J., \& Felder, R.M. (2006). Inductive teaching and learning methods: Definitions, comparisons, and research bases. Journal of Engineering Education, 95, 123-138.

Prosser, M, Trigwell, K., \& Taylor, P. (1994.) A phenomenographic study of academics' conceptions of science learning and teaching. Learning and Instruction, 4, 217-231.

Reisberg, L. (1998). Research by undergraduates proliferates, but is some of it just glorified homework? The Chronicles of Higher Education, 20, A45-A46.

Seel, N.M. (2011). Encyclopedia of the sciences of learning. Springer Science \& Business Media.

Springer, L., Stanne, M.E., \& Donovan, S.S. (1999). Effects of small-group learning on undergraduates in science, mathematics, engineering, and technology: A meta-analysis. Review of Educational Research, 69, 21-51.

Stamp, N., Tan-Wilson, A., \& Silva, A. (2015). Preparing graduate students and undergraduates for interdisciplinary research. BioScience, 65(4), 431-439.

Terenzini, P.T., \& Pascarella, E.T. (1980). Toward the validation of Tinto's model of college student attrition: A review of recent studies. Research in Higher Education, 12, 271.

Terenzini, P.T., \& Wright, T.M. (1987). Influences on students' academic growth during four years of college. Research in Higher Education, 26, 161.

Trowler, V. (2010). Student engagement literature review. The Higher Education Academy, 11, 1-15.

Von Humboldt, W. (1969). Theorie der Bildung des Menschen. Werke in fünf Bänden, 235.

Wallin, P., \& Adawi, T. (2018). Entry points when undergraduate research mentors reflect on their role: a qualitative case study. International Journal for Academic Development, 23(1), 41-51.

Willison, J., \& O'Regan, K. (2007). Commonly known, commonly not known, totally unknown: A framework for students becoming researchers. Higher Education Research \& Development 26, 393409.

Wright, R., \& Boggs, J. (2002). Learning cell biology as a team: Aproject-based approach to upper-division cell biology. Cell Biology Education, 1(4):145-53.

York, T.T., Gibson, C. \& Rankin, S. (2015) Defining and measuring academic success. Practical Assessment, Research \& Evaluation, 20(5), 1-20.

Zepke, N., \& Leach, L. (2010). Improving student engagement: Ten proposals for action. Active Learning in Higher Education, 11(3), 167-177. 